\title{
Biomass and production of plankton in shallow and deep lakes : are there general patterns?
}

\author{
G. Lacroix ${ }^{1}$ \\ F. Lescher-Moutoué 1 \\ A. Bertolo 1
}

Keywords : plankton, biomass, production, efficiency, trophic interactions, lake, depth.

Empirical models were established, which link the biomasses or productions of the successive planktonic trophic levels in lakes of different depth and trophic status. Published data on 56 lakes were analysed, using both least-square and reduced-major-axis regressions. Reduced-major-axes regression technique was used in order to take into account variability due to both bottom-up and top-down forces. In shallow lakes, the energy transfer efficiency between phytoplankton and zooplankton decreases with increasing trophy. An inverse tendency appears in deep lakes. However, when considering only the oligo- and mesotrophic temperate lakes, the mean primary and secondary productivities per unit of area are about the same in shallow and in deep sites. On the other hand, shallow water bodies are characterized by a smaller mean size of the crustacean species, a lower mean biomass of zooplankton and a higher $\mathrm{P}_{\mathrm{zoo}} / \mathrm{B}_{\mathrm{zoo}}$ ratio than deep lakes, probably as a response to the predation by fish. While the consumers seem to have a strong influence on the size structure and biomass of plankton, the energy flows between the trophic levels could be largely controlled by bottom-up forces.

Biomasse et production du plancton dans les lacs profonds et peu profonds : existe-t-il des règles générales ?

Mots-clés : plancton, biomasse, production, efficience, interactions trophiques, lacs, profondeur.

Des modèles empiriques ont été établis afin d'analyser les relations entre les biomasses et les productions de niveaux trophiques successifs au sein de communautés planctoniques lacustres. Des données de la littérature, concernant 56 de lacs de profondeurs et de statuts trophiques variés, ont été collectées et analysées à l'aide de modèles de régression linéaires établis selon les techniques des moindres carrés et de l'axe majeur réduit. Cette dernière technique a été utilisée afin de tenir compte simultanément des forces de contrôle ascendantes et descendantes au sein des réseaux trophiques. Dans les lacs peu profonds, l'efficacité des transferts énergétiques entre le phytoplancton et le zooplancton diminue avec le statut trophique des lacs. Une tendance inverse caractérise les lacs profonds. Cependant, les transferts énergétiques semblent s'effectuer avec une efficacité similaire lorsqu'on ne prend pas en compte les lacs ultra-oligotrophes. Par ailleurs, les lacs peu profonds sont caractérisés par des microcrustacés planctoniques de plus petite taille, une plus faible biomasse zooplanctonique et un rapport $\mathrm{P}_{\mathrm{zoo}} / \mathrm{B}_{\mathrm{zoo}}$ inférieur par rapport à ce que l'on observe dans les lacs profonds, probablement du fait d'une plus forte pression de prédation par les poissons. Alors que les prédateurs semblent jouer un rôle important dans le contrôle de la structure en taille et de la biomasse du plancton, les flux d'énergie entre niveaux trophiques successifs semblent essentiellement contrôlés par les ressources.

\section{Introduction}

Empirical predictive models on the characteristics of the plankton communities of lakes became increasingly important in the last decades. Most of these studies

\footnotetext{
1. Laboratoire d'Ecologie, CNRS-UMR 7625, Ecole Normale Supérieure, 46 rue d'Ulm, 75230 Paris Cedex 05, France. E-mail: lacroix@biologie.ens.fr
}

dealt with the biomass and production of phytoplankton, in particular with the factors regulating the biomass of phytoplankton as measured by chlorophyll $a$ concentrations (see Dillon \& Rigler 1974, McCauley et al. 1989, Prairie et al. 1989, Mazumder 1994, Mazumder \& Havens 1998). Some other papers deal with zooplankton biomass (see McCauley \& Kalff 1981, Mills \& Schiavone 1982, Hanson \& Peters 1984, Pace 1984, 1986, Jeppesen et al. 1997), or zooplankton production (Brylinsky \& Mann 1973, Hillbricht-Ilkowska 1977, Brylinsky 1980). Some questions remain contro- 
versial, such as the evolution of the efficiency of zooplanktonic production with the increase of trophy (see Hillbricht-Ilkowska 1977, Makarewicz \& Likens 1979, McCauley \& Kalff 1981).

Moreover, variability in food-web structure and topdown control among lakes could have significant impact on the ecological processes and on the regulation of the different trophic levels (see Carpenter et al. 1985, Persson et al. 1988, Power 1992, Lacroix et al. 1996). The relative importance of bottom-up control versus top-down control could partly depend upon lake morphometry and mixing regime. Mazumder (1994) demonstrated that the phosphorus-chlorophyll relationship is influenced by thermal mixing regime (with or without stratification) and foodweb structure (presence or absence of large-bodied Daphnia). Lake depth is suspected to have a great influence on the plankton communities and ecosystem functions through light limitation (Petersen et al. 1997), wind effect (Carper \& Bachmann 1984), nutrient dynamics (Sondergaard et al. 1992), distribution patterns of plankton (Pinel-Alloul et al. 1998), and intensity of fish predation (Jeppesen et al. 1997). Few papers compared the biomass and productivity of plankton in shallow and deep lakes. A total of 56 water bodies of various depths and trophic types were retained in the present study, for making such an analysis.

\section{Methods}

The characteristics of the 56 water bodies, distributed all over the northern hemisphere (except two equatorial lakes), were found in the literature (Annex 1).
The range of variation and unit of the different variables are given in Table 1. The geographical parameters were latitude (LAT) and altitude, the morphometrical parameters were the mean depth $\left(Z_{\text {mean }}\right)$, the maximal depth $\left(Z_{\max }\right)$ and the lake area. Annual productions $\left(\mathrm{P}_{\text {phyto }}, \mathrm{P}_{\mathrm{zoO}}, \mathrm{P}_{\text {herb }}\right.$ and $\left.\mathrm{P}_{\text {carn }}\right)$ and mean biomasses $\left(B_{\text {phyto }}, B_{z o o}, B_{\text {herb }}\right.$ and $\left.B_{\text {carn }}\right)$ were considered for phytoplankton, total zooplankton, herbivorous and carnivorous zooplankton. In the northern lakes, the productivity values are generally defined for the growing season only. These values were considered similar to the annual ones since the winter productivity is very low.

Least-squares multiple regression analyses were performed to determine which of the abiotic and biotic characteristics of the lakes are significantly related to the annual zooplankton production. Variables were transformed into their logarithms in order to straighten the relation and to improve the homogeneity of the error variance. Stepwise analyses were run. At each step, the probability level for addition or elimination of a variable was $p=0.05$.

To account for a possible effect of water depth on the variables considered, the lakes were arbitrarily divided into «shallow» and «deep» categories (26 shallow lakes with $\mathrm{Z}_{\text {mean }}<6 \mathrm{~m}$ or $\mathrm{Z}_{\text {max }}<10 \mathrm{~m}$, and 30 deep lakes with $Z_{\text {mean }} \geq 6 \mathrm{~m}$ and $Z_{\text {max }} \geq 10 \mathrm{~m}$ ). The influence of depth on zooplankton biomass and production was evaluated by comparing the regression equations for each class, or by adding a dummy variable (SHALLOW) in the stepwise regression analysis: SHALLOW $=1$ if $\mathrm{Z}_{\text {mean }}<6 \mathrm{~m}$ or $\mathrm{Z}_{\max }<10 \mathrm{~m}$, and SHALLOW = 0 if not (for details, see Tomassone et al. 1983).

Table 1. Minimal, mean, and maximal values of the biotic and abiotic parameters which characterize the different lakes ( $n=$ number of water bodies for which the data were available).

Tableau 1. Valeurs minimales, moyennes et maximales des paramètres biotiques et abiotiques caractérisant les différents lacs $(\mathrm{n}=$ nombre de plans d'eau pour lesquels les données étaient disponibles).

\begin{tabular}{|c|c|c|c|c|c|}
\hline Parameter & Unit & $\mathrm{n}$ & Min. & Mean & Max. \\
\hline Latitude & $\circ$, & 56 & $0^{\circ} \mathrm{N}$ & $50^{\circ} \mathrm{N}$ & $74^{\circ} 42^{\prime} \mathrm{N}$ \\
\hline Altitude & $\mathbf{m}$ & 47 & 0 & 428 & 2320 \\
\hline Mean depth & $\mathrm{m}$ & 56 & 0.6 & 23.6 & 730 \\
\hline Maximal depth & $\mathrm{m}$ & 56 & 1.5 & 55.4 & 1620 \\
\hline Area & $\mathrm{km}^{2}$ & 55 & 0.004 & 1092 & 31500 \\
\hline Phytoplankton biomass & $\mathrm{g} \mathrm{C} \mathrm{m}^{-2}$ & 30 & 0.022 & 2.10 & 9.60 \\
\hline Phytoplankton production & $\mathrm{g} \mathrm{C} \mathrm{m}^{-2} \mathrm{y}^{-1}$ & 56 & 2.24 & 202 & 2112 \\
\hline Zooplankton biomass & $\mathrm{g} \mathrm{C} \mathrm{m}^{-2}$ & 48 & 0.01 & 0.75 & 6.18 \\
\hline Zooplankton production & $\mathrm{g} \mathrm{C} \mathrm{m}^{-2} \mathrm{y}^{-1}$ & 53 & 0.04 & 14.20 & 78.20 \\
\hline$\left(\mathrm{P}_{\text {zoo }} / \mathrm{P}_{\text {phyto }}\right) \times 100$ & $\%$ & 53 & 1.3 & 12.0 & 37.1 \\
\hline
\end{tabular}


The productions of the successive levels of a food chain are subject to important natural variability. Moreover, since both bottom-up and top-down forces control the pelagic food webs (see McQueen et al. 1986, Carpenter 1988), these productions are likely to be interdependent. Thus, the model of the reduced-major-axis was compared to the more classical leastsquares method in order to better estimate the functional relationship between the productions of two successive trophic levels. The least-squares method is totally justified when a dependent variable $Y$ can be expressed as a function of an independent variable $X$, which is known without error. The regression of $Y$ on $X$ minimizes the sum of the squared differences between the estimated and observed $Y$ values. When both $\mathrm{X}$ and $\mathrm{Y}$ can be considered as interdependent and are subject to inherent variability, there is no reason to minimize the residual variance of $Y$ rather than the residual variance of $X$. In this case, the least-squares method underestimates the true value of the slope of the regression line. This underestimation can be very important when the correlation between the two variables is weak. Other statistical techniques, as the reducedmajor-axis analysis, are more suitable to establish the functional relationship between such variables (see Dagnelie 1973, 1975, Ricker 1973). The slope of the reduced-major-axis is the ratio of the standard deviation of $\mathrm{Y}$ to the standard deviation of $\mathrm{X}$, which is equivalent to the slope obtained with the least-squares model divided by the correlation coefficient.
Because not all variables were available for each lake, certain water bodies were used for some models but not all. Tests on the slopes of the least-squares and reduced-major-axis models were made according to Dagnelie (1973). The statistical analyses were carried out by using the SuperANOVA and Stat-View software packages.

\section{Results}

\subsection{Phytoplankton production versus zooplankton production}

Highly significant $(p<0.0001$, Table 2$)$ linear relationships exist between the logarithms of the phytoplankton production and the logarithms of the productions of both herbivorous zooplankton $\left(r^{2}=0.72\right)$ and total zooplankton $\left(r^{2}=0.68\right)$. A quadratic term, (log $\left.\mathrm{P}_{\text {phyto }}\right)^{2}$, which could account for a curvilinear relationship, was not retained by the stepwise procedure.

The slopes of the regression lines obtained with either the least-squares model or the reduced-major-axis model do not significantly differ from 1 ( $t$-test, Table 2 ). Such a result indicates that the ecological efficiencies, $\mathrm{P}_{\text {herb }} / \mathrm{P}_{\text {phyto }}$ and $\mathrm{P}_{\text {zoo }} / \mathrm{P}_{\text {phyto }}$, do not vary significantly with the trophic status of the lakes. The mean efficiency of production of the zooplankton is $0.120 \pm$ 0.013 S.E. $(n=53)$ and that of the herbivorous zooplankton is $0.111 \pm 0.015$ S.E. $(n=36)$.

A highly significant negative correlation exists between primary production and latitude (Spearman cor-

Table 2: Relationship between the logarithms of phytoplankton production and the logarithms of the productions of herbivores or total zooplankton, expressed in. $\mathrm{C} \mathrm{m}^{-2} \mathrm{y}^{-1}$. Equations obtained with the least squares model (I) or the reduced-major-axis model (II). Number of lakes (n), standard error of the slope $\left(\mathrm{SE}_{\mathrm{b}}\right)$, correlation coefficient $(r)$ and associated probability $(p), *, * *, * * *$ : the estimated slope significantly differs from 1 ( $t$-test, $p<0.05, p<0.01$, and $p<0.001$ respectively).

Tableau 2. Relations entre les logarithmes de la production phytoplanctonique et les logarithmes de la production des herbivores ou de la production totale du zooplancton (en $\mathrm{g} \mathrm{C} \mathrm{m}^{-2} \mathrm{an}^{-1}$ ) $\cdot$ Les équations sont obtenues soit par la technique des moindres carrés (I), soit par la technique de l'axe majeur réduit (II). Nombre de lacs $(\mathrm{n})$, erreur-standard sur la pente $\left(\mathrm{SE}_{\mathrm{b}}\right)$, coefficient de corrélation $(r)$ et probabilité associée $(p) .^{*},{ }^{* *}, * * *$ : la pente estimée diffère significativement de 1 ( $t$-test, $p<0.05, p<0.01$, et $p<0.001$ respectivement).

\begin{tabular}{|c|c|c|c|c|c|c|}
\hline $\mathbf{n}$ & Model & a & b & $\mathrm{SE}_{\mathrm{b}}$ & $r$ & $p$ \\
\hline \multicolumn{7}{|c|}{$\log P_{\text {herb }}=a+b \log P_{\text {phyto }}$} \\
\hline \multirow[t]{2}{*}{36} & I & -1.089 & 0.989 & 0.106 & 0.848 & $<0.0001$ \\
\hline & II & -1.428 & 1.167 & & & \\
\hline \multicolumn{7}{|c|}{$\log P_{z 0 o}=a+b \log P_{\text {phyto }}$} \\
\hline \multirow[t]{2}{*}{53} & I & -0.731 & 0.824 & 0.080 & 0.822 & $<0.0001$ \\
\hline & II & -1.071 & 1.002 & & & \\
\hline
\end{tabular}


relation, $\left.r_{\mathrm{S}}=-0.49, \mathrm{n}=56, p=0.0003\right)$. This classical result (Brylinsky \& Mann 1973) mainly reflects variations in input of solar energy. In order to reduce the interference of the climatic conditions in the relationship between $\log \mathrm{P}_{\text {phyto }}$ and $\log \mathrm{P}_{\mathrm{zoo}}$, we considered only the lowland temperate lakes (latitude: $34^{\circ} \mathrm{N}$ to $59^{\circ} \mathrm{N}$, altitude $<500 \mathrm{~m}$ ). As observed for all the water bodies, $\log$ $\mathrm{P}_{\text {phyto }}$ and $\log \mathrm{P}_{\mathrm{zoo}}$ are highly correlated $\left(r^{2}=0.57, \mathrm{n}=\right.$ $25, p<0.0001$ ), and the slope of the reduced-major-axis model $(b=1.19)$ does not significantly differ from 1 .

The regression equations respectively obtained for «shallow» and «deep» lakes differ significantly. The slopes of the two regression models which characterize shallow lakes are significantly $<1$ (Table 3 ). The efficiency of secondary production in those lakes is thus a decreasing function of trophy. For the deep lakes, on the contrary, the slope of the least-square model does not differ from unity while the slope of the reducedmajor-axis is significantly $>1$ (Table 3 ). Differences between the two categories of lakes are clearly due to a few ultra-oligotrophic lakes $\left(\mathrm{P}_{\text {phyto }}<20 \mathrm{~g} \mathrm{C} \mathrm{m}^{-2} \mathrm{y}^{-1}\right.$, Fig. 1), while the efficiencies of production $\left(\mathrm{P}_{\mathrm{zoo}} / \mathrm{P}_{\mathrm{phy}}\right.$ to ) converge in deep and shallow water bodies from oligotrophic to eutrophic conditions (Table 4). Depth has actually no significant influence on the energy transfer efficiency in oligotrophic or mesotrophic lakes (20 $\leq$ $\mathrm{P}_{\text {phyto }}<350$ ). In eutrophic conditions, the $\mathrm{P}_{\text {zoo }} / \mathrm{P}_{\text {phyto }}$ ratio seems to decrease in both shallow and deep lakes (Table 4). However, we could not test for a curvilinear relationship between the productions of phytoplankton and zooplankton in deep lakes, due the rarity of eutrophic water bodies in the data set.

Table 3. Relationship between the logarithms of the productions of phytoplankton and total zooplankton, expressed in $\mathrm{g} \mathrm{C} \mathrm{m}^{-2} \mathrm{y}^{-1}$, in deep and in shallow lakes. Symbols for parameters are explained in Table 2.

Tableau 3. Relation entre les logarithmes de la production phytoplanctonique et de la production totale du zooplancton, exprimée en $\mathrm{g} \mathrm{C} \mathrm{m}^{-2}$ an-1, dans les lacs profonds et peu profonds. Mêmes symboles que dans le Tableau 2.

\begin{tabular}{ccccccc}
\hline $\mathrm{n}$ & Model & $\mathrm{a}$ & $\mathrm{b}$ & $\mathrm{SE}_{\mathrm{b}}$ & $r$ & $p$ \\
\hline $\log \mathrm{P}_{\mathrm{zoo}}=\mathrm{a}+\mathrm{b} \log \mathrm{P}_{\text {phyto }}$ (shallow lakes) \\
26 & I & -0.174 & $0.561^{* * *}$ & 0.093 & 0.775 & $<0.0001$ \\
& II & -0.516 & $0.723^{* *}$ & & & \\
$\log \mathrm{P}_{\text {zoo }}=\mathrm{a}+\mathrm{b} \log \mathrm{P}_{\text {phyto }}$ (deep lakes) \\
27 & I & -1.164 & 1.073 & 0.121 & 0.871 & $<0.0001$ \\
& II & -1.439 & $1.232^{*}$ & & & \\
\hline
\end{tabular}

Table 4. Evolution of the mean $\mathrm{P}_{\mathrm{zoo}} / \mathrm{P}_{\text {phyto }}$ ratio according to the trophic status and the depth of lakes. Trophic categories are defined from Wetzel (1975), according to the $P_{\text {phyto }}$ values $\left(\mathrm{g} \mathrm{C} \mathrm{m}^{-2} \mathrm{y}^{-1}\right)$ : ultra-oligotrophic $\left(\mathrm{P}_{\text {phyto }}<20\right)$, oligotrophic $\left(20 \leq \mathrm{P}_{\text {phyto }}<100\right)$, mesotrophic $\left(100 \leq \mathrm{P}_{\text {phyto }}<350\right)$, eutrophic $\left(\mathrm{P}_{\text {phyto }} \geq 350\right)$. $\mathrm{n}$ represents the number of water bodies in each category. SE represents the standard error ot the mean.

Tableau 4. Evolution du rapport moyen $P_{z o o} / P_{\text {phyto }}$ en relation avec le statut trophique et la profondeur des lacs. Les catégories trophiques sont celles établies par Wetzel (1975) à partir des valeurs de la production phytoplanctonique $P_{\text {phyto }}$ $\left(\mathrm{g} \mathrm{C} \mathrm{m}^{-2}\right.$ an $\left.^{-1}\right)$ : ultra-oligotrophe $\left(\mathrm{P}_{\text {phyto }}<20\right)$, oligotrophe $\left(20 \leq \mathrm{P}_{\text {phyto }}<100\right)$, mesotrophe $\left(100 \leq \mathrm{P}_{\text {phyto }}<350\right)$, eutrophe $\left(\mathrm{P}_{\mathrm{phyto}} \geq 350\right)$. $\mathrm{n}$ : nombre de plans d'eau pour chaque catégorie. $\mathrm{SE}$ : erreur standard de la moyenne.

\begin{tabular}{lrlrlrl}
\hline & \multicolumn{2}{c}{ Shallow lakes } & & \multicolumn{2}{c}{ Deep lakes } \\
\cline { 2 - 3 } \cline { 5 - 6 } Trophic category & $\mathrm{n}$ & $\mathrm{P}_{\text {zoo }} / \mathrm{P}_{\text {phyto }} \pm \mathrm{SE}$ & & $\mathrm{n}$ & $\mathrm{P}_{\text {zoo }} / \mathrm{P}_{\text {phyto }} \quad \pm \mathrm{SE}$ \\
\hline Ultra-oligotrophic & 3 & $0.297 \pm 0.044$ & & 7 & $0.172 \pm 0.054$ \\
Oligotrophic & 5 & $0.107 \pm 0.018$ & & & $0.114 \pm 0.039$ \\
Mesotrophic & 12 & $0.093 \pm 0.022$ & & 11 & $0.114 \pm 0.015$ \\
Eutrophic & 6 & $0.070 \pm 0.031$ & & 1 & 0.052 \\
\hline
\end{tabular}




\subsection{Relationship between phytoplankton and zoo- plankton biomasses}

A significant correlation ( $p=0.038$ ) was observed between the logarithms of the phytoplankton and zooplankton biomasses in the 28 lakes for which such data were available (Table 5). The geographical and morphometrical variables were not retained by the stepwise procedure. Because of the weak correlation between $\log \mathrm{B}_{\text {phyto }}$ and $\log \mathrm{B}_{\mathrm{zoo}}\left(r^{2}=0.16\right)$, the slope of the functional regression line (reduced-major-axis) is
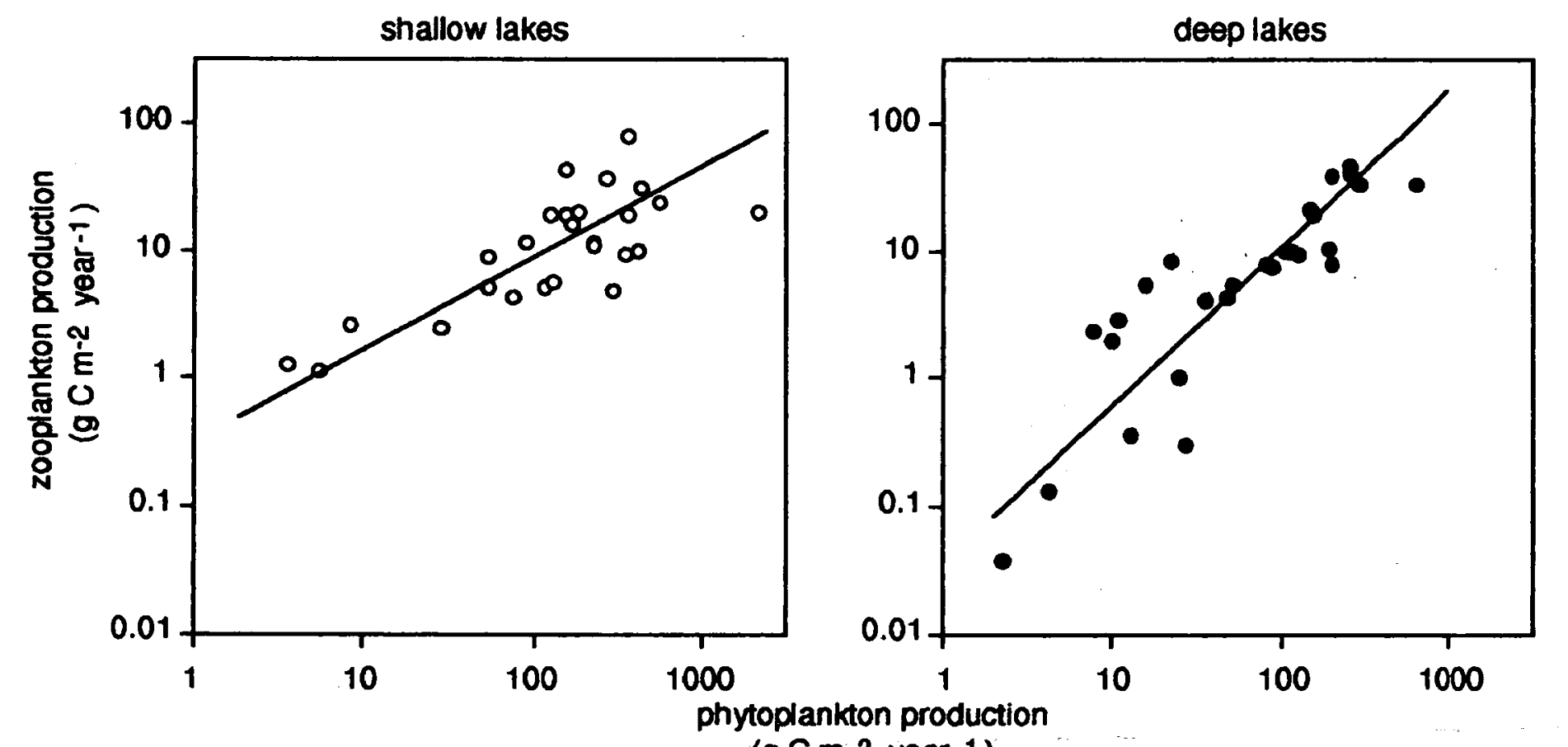

(g C m-2 year-1)

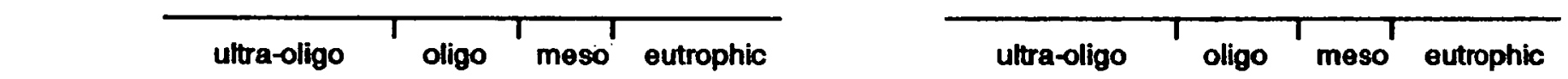

considerably greater than the slope obtained with the least-squares model. However, both are significantly less than 1 . This suggests that the ratio of zooplankton to phytoplankton biomass $\left(\mathrm{B}_{\mathrm{zoo}} / \mathrm{B}_{\text {phyto }}\right)$ decreases with increasing trophy. To verify if this actually corresponded to a climatic or a morphometrical trend, we investigated the relationship between the geographical and morphometrical factors and the logarithms of phytoplankton biomass. No significant relationship was observed.

Fig. 1. Relationship between phytoplankton production and zooplankton production in shallow and deep lakes (log-log scale). The fitted lines represent the reduced-major-axis. See Table 4, for the definition of trophic categories.

Fig. 1. Relation entre la production phytoplanctonique et la production zooplanctonique dans les lacs peu profonds et les lacs profonds (échelle $\log -\log$ ). Les traits ajustés représentent les axes majeurs réduits. Voir le Tableau 4 pour la définition des catégories trophiques.

Table 5. Relationship between the logarithms of the mean biomasses of phytoplankton and zooplankton, expressed in $\mathrm{g} \mathrm{C} \mathrm{m}^{-2}$. Relationship between annual productions estimated on the same data set. Symbols for parameters are explained in Table 2.

Tableau 5. Relation entre les logarithmes des biomasses moyennes du phytoplancton et du zooplancton ( $\mathrm{g}$ $\mathrm{C} \mathrm{m}^{-2}$ ). Relation entre les productions annuelles pour le même jeu de données. Mêmes symboles que dans le Tableau 2.

\begin{tabular}{|c|c|c|c|c|c|c|}
\hline $\mathbf{n}$ & Model & a & $\mathbf{b}$ & $\mathrm{SE}_{\mathbf{b}}$ & $r$ & $p$ \\
\hline \multicolumn{7}{|c|}{$\log B_{z o 0}=a+b \log B_{\text {phyto }}$} \\
\hline \multirow[t]{2}{*}{28} & I & -0.229 & $0.268^{* * *}$ & 0.122 & 0.395 & 0.0377 \\
\hline & II & -0.221 & $0.678^{*}$ & & & \\
\hline \multicolumn{7}{|c|}{$\log P_{z 00}=a+b \log P_{\text {phyto }}$} \\
\hline \multirow[t]{2}{*}{28} & I & -0.473 & $0.750^{*}$ & 0.093 & 0.846 & $<0.0001$ \\
\hline & II & -0.749 & 0.887 & & & \\
\hline
\end{tabular}


In contrast with the results obtained with the whole data set (Table 2), the slope of the least-squares regression between $\log \mathrm{P}_{\text {phyto }}$ and $\log \mathrm{P}_{\mathrm{zoo}}$ is significantly $<1$ when only the 28 lakes used to establish the relationship between planktonic biomasses are considered (Table 5). However, the functional regression (reduced-major-axis) between the logarithms of $P_{\text {phyto }}$ and $P_{z o o}$ does not significantly differ from 1 (Table 5). Thus, the observed reduction of the $B_{z o o} / B_{\text {phyto }}$ ratio with increasing trophy is probably not accompanied by a similar decrease in the efficiency of secondary production.

\subsection{Carnivorous versus herbivorous zooplankton}

Highly significant $(p<0.0001)$ linear relationships exist between the logarithms of both biomasses $\left(r^{2}=\right.$ $0.67)$ and productions $\left(r^{2}=0.84\right)$ of herbivorous and carnivorous zooplankton (Fig. 2, Table 6). In both cases, the slopes of the least-squares and functional models do not differ significantly from unity. No significant effect of geographical factors and lake depth was recorded. The $\mathrm{P}_{\text {carn }} / \mathrm{P}_{\text {herb }}$ mean ratio is $0.174 \pm 0.027$.

\subsection{Relationship between production and biomass of zooplankton}

The logarithms of production and biomass of total zooplankton are highly correlated $\left(r^{2}=0.67, p<\right.$ 0.0001 ) (Fig. 3). The logarithms of lake latitude and altitude were not retained in the stepwise procedure. A significant positive effect of the variable SHALLOW is revealed by the stepwise procedure (Table 7). According to the equation given in Table 7 , the predicted productivity would be about twofold higher in shallow lakes (SHALLOW =1) than in deep ones (SHALLOW $=0$ ), for a same value of zooplankton biomass. For better examining the effect of depth, we compared the

Table 6. Relationships between the logarithms of the mean biomasses $\left(\log B_{c a r n}=a+b \log B_{\text {herb }}\right)$ and between the logarithms of the productions $\left(\log \mathrm{P}_{c a r n}=\mathrm{a}+\mathrm{b} \log \mathrm{P}_{\text {herb }}\right)$ of herbivorous zooplankton and carnivorous zooplankton. Biomasses and productions are expressed in $\mathrm{g} \mathrm{C} \mathrm{m}^{-2}$ and $\mathrm{g} \mathrm{C} \mathrm{m}^{-2} \mathrm{y}^{-1}$ respectively. Symbols for parameters are explained in Table 2.

Tableau 6. Relations entre les logarithmes des biomasses moyennes $\left(\log B_{c a m n}=a+b \log B_{\text {herb }}\right)$ et les logarithmes des productions $\left(\log \mathrm{P}_{\text {carn }}=\mathrm{a}+\mathrm{b} \log \mathrm{P}_{\text {herb }}\right)$ du zooplancton herbivore et carnivore. Biomasse et production respectivement en $\mathrm{g} \mathrm{C} \mathrm{m}^{-2}$ and $\mathrm{g} \mathrm{C} \mathrm{m}^{-2}$ an $^{-1}$. Mêmes symboles que dans le Tableau 2.

\begin{tabular}{rrrrrrr}
\hline $\mathrm{n}$ & Model & $\mathrm{a}$ & $\mathrm{b}$ & $\mathrm{SE}_{\mathrm{b}}$ & $r$ & $p$ \\
\hline \multicolumn{2}{l}{$\log \mathrm{B}_{\text {carn }}=\mathrm{a}+\mathrm{b} \log \mathrm{B}_{\text {herb }}$} \\
26 & I & -0.780 & 0.953 & 0.137 & 0.818 & $<0.0001$ \\
& II & -0.693 & 1.165 & & & \\
$\log \mathrm{P}_{\text {carn }}=\mathrm{a}+\mathrm{b} \log \mathrm{P}_{\text {herb }}$ & & & & & \\
31 & I & -0.882 & 1.020 & 0.081 & 0.916 & $<0.0001$ \\
& II & -0.956 & 1.114 & & & \\
\hline
\end{tabular}

Table 7. Relationship between the logarithms of zooplankton production $\left(\mathrm{g} \mathrm{C} \mathrm{m}^{-2} \mathrm{y}^{-1}\right)$ and the logarithms of mean zooplankton biomass $\left(\mathrm{g} \mathrm{C} \mathrm{m}^{-2}\right)$ according to lake depth ( $\mathrm{n}=48$ observations) : $\log$ $P_{z 00}=b_{1} \log B_{z 00}+b_{2}$ SHALLOW $+b_{3}$. Variables are given by order of their entry in the stepwise procedure. For each variable, $t$-test and associated probability $(p)$; coefficient of determination $\left(r^{2}\right)$.

Tableau 7. Relation entre les logarithmes de la production zooplanctonique $\left(\mathrm{g} \mathrm{C} \mathrm{m}^{-2} \mathrm{an}^{-1}\right)$ et les logarithmes de la biomasse zooplanctonique moyenne $\left(\mathrm{g} \mathrm{C} \mathrm{m}^{-2}\right)$ en fonction de la profondeur des lacs ( $n=48$ observations) :

$\log P_{z 00}=b_{1} \log B_{z 00}+b_{2}$ SHALLOW $+b_{3}$. Les variables sont données selon leur ordre d'entrée dans la procédure pas à pas. $t$-test et probabilité associée $(p)$ pour chaque variable ; coefficient de détermination $\left(r^{2}\right)$.

\begin{tabular}{lllrr}
\hline Variable & $\mathrm{b}_{\mathrm{i}}$ & $\mathrm{SE}_{\mathrm{bi}}$ & \multicolumn{1}{c}{$t$-test } & \multicolumn{1}{c}{$p$} \\
\hline $\log \mathrm{B}_{\text {zoo }}$ & 1.012 & 0.111 & 9.111 & $<0.0001$ \\
SHALLOW & 0.260 & 0.114 & 2.291 & 0.0267 \\
Y intercept: & 1.115 & 0.091 & 12.270 & $<0.0001$ \\
$\left(\mathrm{r}^{2}=0.674\right)$ & & & & \\
\hline
\end{tabular}




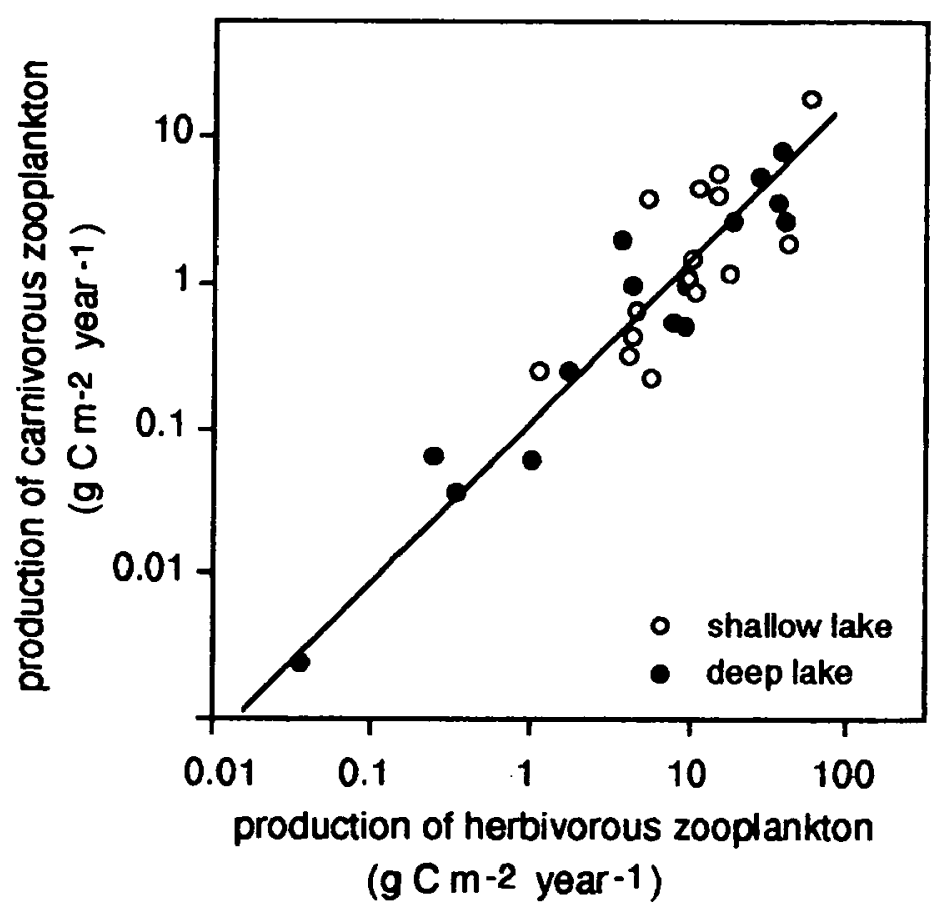

Fig. 2. Relationship between the productions of herbivorous and carnivorous zooplankton in shallow and deep lakes (log-log scale). The fitted line represents the reduced-major-axis.

Fig. 2. Relation entre les productions du zooplancton herbivore et carnivore dans les lacs peu profonds et profonds (échelle log-log). Les traits ajustés représentent l'axe majeur réduit.

zooplanktonic biomasses and productions of the «shallow» and «deep» lowland lakes situated between $34^{\circ} \mathrm{N}$ and $59^{\circ} \mathrm{N}$, in order to control for the variability related to solar energy input. The zooplankton production is on average very similar in the two categories of lakes but the mean biomass tends to be lower in shallow lakes (Table 8). Thus, a significantly higher $\mathrm{P}_{\mathrm{zoo}} / \mathrm{B}_{\mathrm{zoo}}$ ratio in shallow lakes seems to be essentially linked to a lower mean biomass and not to a higher production of zooplankton.

Specific P/B values are known to increase with decreasing body-size of zooplankton (Waters 1977, Downing 1984). Mean size of crustacean species was roughly estimated on the basis of the known taxonomic compositions of the different lake communities. The mean body-length of crustacean species is significantly smaller in shallow lakes (Table 8).

\section{Discussion}

Persson et al. (1988) questioned the use of a simple regression approach to analyse the interactions between different trophic levels of a food web. They argued that, although the biomass of the different trophic levels is significantly related to the nutrient loading, substantial variance remains unexplained. They added that «both the number of trophic levels in the system and the position of the level in relation to the top one

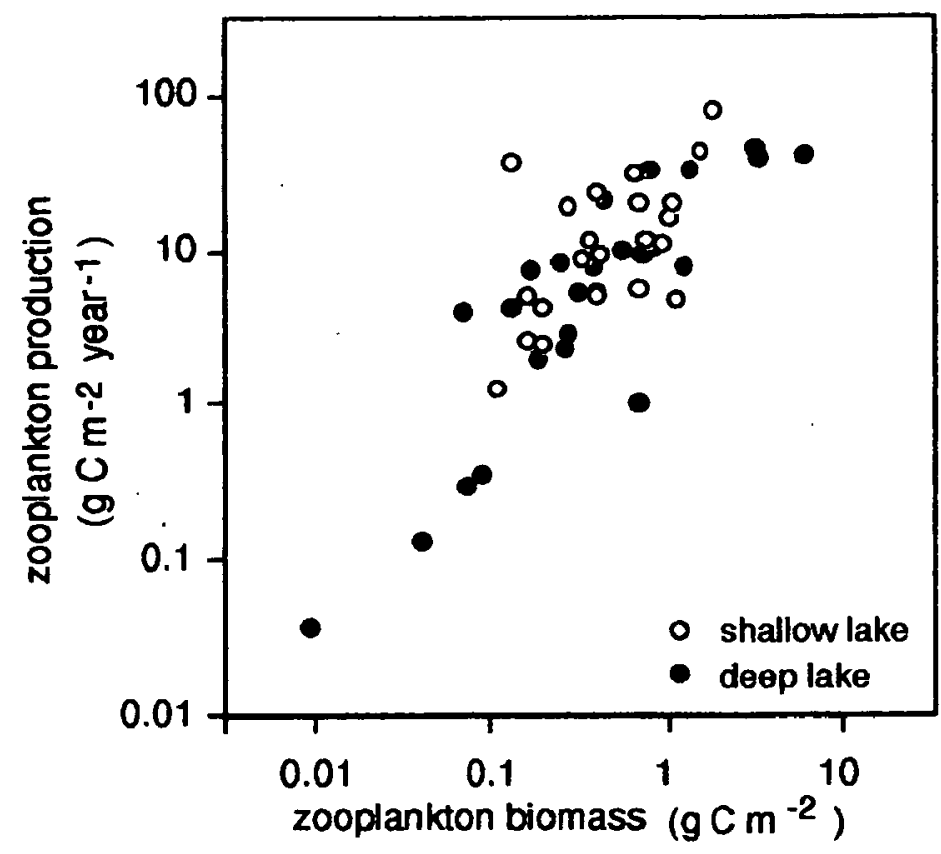

Fig. 3. Relationship between the biomass and the production of zooplankton in shallow and deep lakes (log-log scale).

Fig. 3. Relation entre la biomasse et la production du zooplancton dans les lacs peu profonds et profonds (échelle log-log)

must be considered» (see also Oksanen et al. 1981). We agree with these considerations. However, in our view, log-log regressions can reveal interesting informations on the general trends which characterize energy transfers between trophic levels and on some of the underlying processes. The highly significant relationships that we found between the productions of the successive levels of the planktonic food webs strengthen our opinion. Moreover, using statistical techniques like reduced-major-axis regression helped to better integrate both bottom-up and top-down forces. The use of more widespread least-square regression could indeed lead in some cases to misleading conclusions (see Table 3 ).

The variations in the energy transfer efficiency with increasing trophy have long been debated. According to Cushing (1970), the $P_{z o o} / P_{\text {phyto }}$ ratio increases with the phytoplankton production in marine upwelling areas of the Pacific Ocean $\left(\mathrm{P}_{\text {phyto }}<0.5 \mathrm{~g} \mathrm{C} \mathrm{m}^{-2} \mathrm{~d}^{-1}\right)$. Hillbricht-Ilkowska (1977) observed that the lowest values of production efficiency for herbivorous zooplankton were obtained in ultra-oligotrophic or eutrophic water bodies. She suggested that the predominance of nanoplankton in oligo-mesotrophic lakes allows a high efficiency of consumption and production by the herbivores while the greater importance of the «detritus food chain» in eutrophic waters would reduce the 
Table 8. Mean characteristics of lowland temperate or continental lakes according to depth. SEm: standard error of the mean; $\mathbf{n}:$ number of lakes. Differences between categories were tested by bilateral non parametric Wilcoxon tests $\left(*: p<0.05 ;\left(^{*}\right): 0.05<p<0.10\right)$.

Tableau 8. Caractéristiques moyennes des lacs de basse altitude tempérés ou continentaux en fonction de la profondeur.SEm : erreur standard sur la moyenne ; $\mathrm{n}$ : nombre de lacs. Les différences entre les catégories ont été testées par le test bilatéral non paramétrique de Wilcoxon $\left(^{*}: p<0.05 ;\left(^{*}\right)\right.$ : $0.05<p<0.10$ ).

\begin{tabular}{lllllr}
\hline Parameter & Unit & $\begin{array}{l}\text { Mean } \pm \text { SEm } \\
\text { in shallow lakes }\end{array}$ & $\begin{array}{l}\mathrm{n} \\
\text { in deep lakes }\end{array}$ & $\begin{array}{l}\text { Mean } \pm \text { SEm } \\
\text { in }\end{array}$ \\
\hline $\mathrm{B}_{\text {phyto }}$ & $\mathrm{g} \mathrm{C} \mathrm{m}^{-2}$ & $2.49 \pm 0.92$ & 10 & $2.58 \pm 0.62$ & 6 \\
$\left.\mathrm{~B}_{\text {zoo }}{ }^{*}\right)$ & $\mathrm{g} \mathrm{C} \mathrm{m}^{-2}$ & $0.71 \pm 0.15$ & 13 & $1.78 \pm 0.61$ & 10 \\
$\mathrm{P}_{\text {phyto }}$ & $\mathrm{g} \mathrm{C} \mathrm{m}^{-2} \mathrm{y}^{-1}$ & $205 \pm 37$ & 14 & $177 \pm 26$ & 13 \\
$\mathrm{P}_{\text {zoo }}$ & $\mathrm{g} \mathrm{C} \mathrm{m}^{-2} \mathrm{y}^{-1}$ & $19.1 \pm 5.5$ & 14 & $20.5 \pm 4.9$ & 11 \\
$\mathrm{P}_{\text {zoo }} / \mathrm{P}_{\text {phyto }}$ & - & $0.100 \pm 0.020$ & 14 & $0.112 \pm 0.015$ & 11 \\
$\mathrm{P}_{\text {zoo }} / \mathrm{B}_{\text {zoo }}$ & - & $28.4 \pm 4.7$ & 13 & $15.7 \pm 2.6$ & 10 \\
Body length & $\mu \mathrm{m}$ & $1190 \pm 100$ & 11 & $1712 \pm 175$ & 6 \\
of Crustacea & & & & & \\
\hline
\end{tabular}

feeding on phytoplankton. On the opposite, Makarewicz and Likens (1979) suggested a positive effect of this «detritus food chain» on the zooplankton production efficiency ( 11 lakes with $P_{\text {phyto }} \leq 200 \mathrm{~g} \mathrm{C} \mathrm{m}^{-2} \mathrm{y}^{-1}$ ). However, McCauley and Kalff (1981) made a new analysis on the same set of data and refuted Makarewicz and Likens' results: the regression coefficient of the equation actually indicates that the $\mathrm{P}_{\text {zoo }} / \mathrm{P}_{\text {phyto }}$ ratio decreases with increasing trophy. They proposed that the reduction in the proportion of nanoplankton with increasing trophy could account for such a decrease in ratio. We did not observe any significant relationship between zooplankton ecological efficiency and lake trophy when considering the total set of data. However, when «deep» and «shallow» lakes were considered separately, contrasting results appeared. Several factors could explain the observed discrepancy between the two categories of water bodies.

In ultra-oligotrophic deep lakes, the abundance of algae could be frequently lower than the threshold food concentration for zooplankton, adversely affecting its growth and reproduction. In such conditions, zooplankton would have only a weak impact on phytoplankton (Carney 1990, Carney \& Elser 1990, Elser \& Goldman 1991), and the energy transfer efficiency between producers and consumers would be low. In accordance with the 'intermediate trophic state hypothesis' (Carney 1990, Carney \& Elser 1990, see also McQueen et al. 1986), this phenomenon should become less important with increasing trophy and this might explain the slope $b$ of $>1$. Deep eutrophic water bodies are rather uncommon (Tilzer 1990). As our data set included only one deep eutrophic lake (with a low
$\mathrm{P}_{\text {zoo }} / \mathrm{P}_{\text {phyto }}$ ratio), we could not confirm statistically the existence of a decline in zooplankton ecological efficiency at the end of the trophic gradient.

On the other hand, a higher algal concentration per unit of volume could allow a better growth rate of zooplankton and a higher $\mathrm{P}_{\text {zoo }} / \mathrm{P}_{\text {phyto }}$ ratio in shallow and very oligotrophic lakes than in deep and very oligotrophic ones. Moreover, periphyton, phytobenthos and detritus could play and important role as alternative food sources for zooplankton in shallow lakes. With increasing trophy, many shallow lakes switch to a more turbid state with high concentration of phytoplankton (Timms \& Moss 1984, Scheffer 1998). The role of other alternative food sources, and thus the $\mathrm{P}_{\mathrm{zoo}} / \mathrm{P}_{\text {phyto }}$ ratio, should decrease. In eutrophic lakes, the decrease of the share of edible algae could explain the very low efficiency (McCauley \& Kalff 1981, McQueen et al. 1986, Benndorf 1995).

Due to their different slopes, the regression lines which characterize the shallow and deep water bodies converge with increasing primary productivity, and the mean efficiencies of production $\left(\mathrm{P}_{\mathrm{zoo}} / \mathrm{P}_{\text {phyto }} \times 100\right)$ are very comparable for all lakes ranging from oligotrophy to mesotrophy. The mean efficiencies estimated from our set of data - $10.9 \%$ for the herbivorous zooplankton and $11.5 \%$ for the total zooplankton - are somewhat lower than that of $13.7 \%$ estimated by Brylinsky and Mann (1973) and $12.4 \%$ by Morgan (1980).

Unlike Hillbricht-Ilkowska (1977), we did not find any significant variation of the efficiency of production of carnivorous zooplankton along a trophic gradient. The mean energy transfer efficiency $(17.4 \%)$ is com- 
parable with that given by Hillbricht-Illkowska (1977) and by Morgan (1980), respectively $20.7 \%$ and $18.5 \%$.

We had not enough data to analyse the effects of depth on the relationship between biomasses at first and second trophic level. Globally, the regression coefficient $b$ of $<1$ between $\log B_{\text {phyto }}$ and $\log B_{z o o}$ is in accordance with the results of many authors (McCauley \& Kalff 1981, Mills \& Schiavone 1982, Hanson \& Peters 1984, Pace 1984). However, our results do not support strongly the causal hypothesis of a decrease in algal edibility proposed by McCauley and Kalff (1981) (see also Benndorf 1995), since no parallel decrease in the production efficiency was observed for the same set of data. A shift towards smaller zooplankton (Taylor 1984) and larger phytoplankton (Watson \& Kalff 1981, Taylor 1984) with increasing trophy could explain this pattern. An increase of predation pressure by planktivorous fish with potential productivity seems to be the more convincing hypothesis. We could not find sufficient information on fish abundance or biomass for the present set of lakes. Thus, we did not analyse directly the effect of fish on plankton biomass and production. However, several recent studies have demonstrated that fish biomass and density per unit of lake area increase with increasing trophy (Hanson \& Leggett 1982, Downing et al. 1990, Jeppesen et al. 1997), while the percentage contribution of carnivorous fish decreases (Persson et al. 1988, Jeppesen et al. 1997). At the same time, predation pressure on zooplankton increases, as indicated by a reduction in the zooplankton:phytoplankton biomass ratio (Jeppesen et al. 1997).

Several studies strongly suggest that fish predation pressure on zooplankton is greater in shallow lakes than in deep lakes (see Sprules 1980, Timms \& Moss 1984, Lescher-Moutoué et al. 1985, Lacroix et al. 1989, Jeppesen et al. 1997). Jeppesen et al. (1997) proposed that for a given concentration of total phosphorus the biomass of fish per unit area is independent of depth, which means that biomass per volume reduces proportionately with mean depth. Our analyses on the discrepancies between shallow and deep lakes are in total accordance with the hypothesis of a stronger topdown control by fish in shallow ones. We observed indeed smaller mean sizes of crustacean species, lower mean biomasses and higher $\mathrm{P} / \mathrm{B}$ values of zooplankton in the shallow water bodies. Despite these clear differences, mean primary and secondary productivities per unit of area, as well as production efficiency appeared to be very similar in the shallow and deep lakes used for this analysis. This seems to indicate that great differences in the plankton community structure have not necessarily dramatic consequences in the global energy transfers between the successive levels of the planktonic food webs and that higher P/B values of zooplankton might partly compensate for lower standing crops per unit of area.

Thus, while the consumers seem to have a strong influence on the size structure and biomass of plankton, our results suggest that the energy flows between the trophic levels could be mainly controlled by bottom-up forces. To our knowledge, only a few comparative (Jeppesen et al. 1997) and experimental studies (Perin et al. 1996, Proulx et al. 1996, Bertolo et al. accepted) have assessed the interaction effects between fish and depth on plankton features and ecosystem function. Specific experiments and comparative approaches should be designed for better understanding the relative importance of top-down and bottom-up processes according to lake depth.

\section{References}

Anderson R.S. 1975. - An assessment of sport-fish production potential in two small alpine waters in Alberta, Canada. In : J. Salanki \& J.E. Ponyi (eds), Limnology of Shallow Waters. Symposia Biologica Hungarica, 15, Akademiai Kiado, Budapest : 205-214.

Beattie M., Bromley H.J., Chambers M., Goldspink R., Vijverberg J., van Zalinge N.P. \& Golterman H.L. 1972. — Limnological studies on Tjeukemeer - a typical Dutch «polder reservoir». $\mathbf{n}: \mathrm{Z}$. Kajak \& A. Hillbricht-Ilkowska (eds), Productivity Problems of Freshwaters. Warszawa-Krakow : 421-445.

Benndorf J. 1995. — Possibilities and limits for controlling eutrophication by biomanipulation. Int. rev. Ges. Hydrobiol., 80 : 519-534.

Bertolo A., Lacroix G. \& Lescher-Moutoué F. accepted. - Scaling food webs in aquatic mesocosms : do the effects of depth override the effects of planktivory?. Oecologia.

Blakar I.A. \& Jacobsen O.J. 1979. - Zooplankton distribution and abundance in seven lakes from Jotunheimen, a Norwegian high mountain area. Arch. Hydrobiol., $85: 277-290$.

Brylinsky M. 1980. - Estimating the productivity of lakes and reservoirs. In : E.D. Le Cren \& R.H. Lowe-McConnell (eds), The Functioning of Freshwater Ecosystems. IBP $22: 411-453$.

Brylinsky M. \& Mann K.H. 1973. - An analysis of factors governing productivity in lakes and reservoirs. Limnol. Oceanogr., $28: 1-14$.

Burgis M.J. 1974. - Revised estimates for the biomass and production of zooplankton in Lake George, Uganda. Freshwat. Biol., $4: 535-541$.

Capblancq J. \& Laville H. 1983. — Le lac de Port-Bielh (Pyrénées): exemple de fonctionnement d'un écosystème lacustre de haute montagne. In : M. Lamotte \& F. Bourlière (eds), Problèmes d'Ecologie. Ecosystèmes Limniques. Masson, Paris : 51-79.

Carmouze J.P., Durand J.-R. \& Lévêque C. (eds) 1983. — Lake Chad. Ecology and Productivity of a Shallow Tropical Ecosystem. Dr W. Junk Publishers, The Hague, 575 p.

Carney H.J. 1990. - A general hypothesis for the strength of food web interactions in relation to trophic state. Verh. Internat. Verein. Limnol., 24 : 487-492. 
Carney H.J. \& Elser J.J. 1990. — Strength of zooplankton-phytoplankton coupling in relation to lake trophic state. In : M.M. Tilzer \& C. Serruya (eds), Ecological structure and function in large lakes. Springer-Verlag, Berlin : 615-631.

Carpenter S.R. (ed.), 1988. - Complex Interactions in Lake Communities. Springer-Verlag, New-York : 283 p.

Carpenter S.R., Kitchell J.F. \& Hodgson J.R. 1985. — Cascading trophic interactions and lake productivity. Fish predation and herbivory can regulate lake ecosystems. BioScience, 35 : 634-639.

Carper G.L. \& Bachmann R.W. 1984. - Wind resuspension of sediments in a Prairie lake. Can. J. Fish. Aquat. Sci., 41 : 1763-1767.

Comita G.W. 1972. - The seasonal zooplankton cycles, production and transformation of energy in Severson Lake, Minnesota. Arch. Hydrobiol., $70: 14-66$.

Cushing D.H. 1970. - Pelagic food chains. Introduction. In : J.H. Steel (ed.), Marine Food Chains. University of California Press : 69-73.

Dagnelie P. 1973. - Théorie et Méthodes Statistiques. Applications Agronomiques. Vol. 1. Presses agronomiques de Gembloux, A.S.B.L., Belgique, 378 p.

Dagnelie P. 1975. - Théorie et Méthodes Statistiques. Applications Agronomiques. Vol. 2. Presses agronomiques de Gembloux, A.S.B.L., Belgique : 463 p.

Dillon P.J \& Rigler F.H. 1974.- The phosphorus-chlorophyll relationships in lakes. Limnol. Oceanogr., 19 : 767-773.

Downing J.A. 1984. - Assessment of secondary production : the first step. In : J.A. Downing \& F.H. Rigler (eds), A Manual on Methods for the Assessment of Secondary Productivity in Fresh Waters. Blackwell Scientific Publications, Oxford : 1-18.

Downing J.A., Plante C. \& Lalonde S. 1990. - Fish production correlated with primary productivity and the morphoedaphic index. Can. J. Fish. Aquat. Sci., 47 : 1929-1936.

Eggers D.M., Bartoo N.W., Rickard N.A., Nelson R.E., Wissmar R.C., Burgner R.L. \& Devol A.H. 1978. - The Lake Washington ecosystem: the perspective from the fish community production and forage base. J. Fish. Res. Board Can., 35 : 1553-1571.

Elser J.J. \& Goldman C.R. 1991. — Zooplankton effects on phytoplankton in lakes of contrasting trophic status. Limnol. Oceanogr., $36: 64-90$.

Galazy G.I. 1984. — Lake Baikal and its production. Verh. Internat. Verein. Limnol., 22 : 1137-1141.

Garnier J. 1983. - Production phytoplanctonique dans un lac de sablière (lac de Créteil, France). Acta CEcol., Ecol. Gener., 4 : 315-329.

Geller W. \& Güde H. 1989. - Lake Constance - the largest German lake. In : W. Lampert \& K.O. Rothhaupt (eds), Limnology in the Federal Republic of Germany. SIL. Carius Druck GmbH, Germany : 9-17.

Grobbelaar J.U. 1985. - Carbon flow in the pelagic zone of a shallow turbid lake inpoundment, Wuras Dam. Arch. Hydrobiol., 103 : $1-24$

Gulati R.D. 1975. - A study on the role of herbivorous zooplankton community as primary consumers of phytoplankton in Dutch lakes. Verh. Internat. Verein. Limnol., 19 : 1202-1210.

Hakkari L. 1978. - On the productivity and ecology of zooplankton and its role as food for fish in some lakes in Central Finland. Biological Research Reports from the University of Jyväskylä, 4 : 3-87.

Hanson J.M. \& Leggett W.C. 1982. - Empirical prediction of fish biomass and weight. Can. J. Fish. Aquat. Sci., 39 : 257-263.

Hanson J.M. \& Peters R.H. 1984. - Empirical prediction of crustacean zooplankton biomass and profundal macrobenthos biomass in lakes. Can. J. Fish. Aquat. Sci., $41: 439-445$.
Hillbricht-Ilkowska A. 1977. — Trophic relations and energy flow in pelagic plankton. Pol. Ecol. Stud., 3, Polish Scientific Publishers, Warszawa : 3-98.

Jeppesen E., Jensen J.P., Sondergaard M., Lauridsen T., Junge Pedersen L. \& Jensen L. 1997. - Top-down control in freshwater lakes : the role of nutrient state, submerged macrophytes and water depth. In : L. Kyfel, A. Prejs \& J.I. Rybak (eds), Shallow Lakes 95'. Hydrobiologia, 342/343 : 151-164.

Jonasson P.M. 1979. - Ecology of eutrophic subarctic Lake Myvatn and the River Laxa. Oikos, 32, 1-2: 308 p.

Jonasson P.M. 1984. - The ecosystem of eutrophic Lake Esrom. In : F.B. Taub (ed.), Lakes and Reservoirs. Ecosystems of the World, 23. Elsevier Sci. Publishers B.V. : 177-204.

Kajak Z. \& Hillbricht-Ilkowska A. (eds) 1972. - Productivity Problems of Freshwaters. PWN Polish Scientific Publishers, Warszawa-Krakow : 918 p.

Lacroix G. 1987. - Ecologie des peuplements de Cladocères des gravières en eau. Thèse de Doctorat de l'Université Paris 6 , Université-Pierre-et-Marie-Curie : 294 p.

Lacroix G., Boët P., Garnier J., Lescher-Moutoué F., Pourriot R. \& Testard P. 1989. - Controlling factors of the planktonic community in the shallow Lake of Créteil. Int. Revue ges. Hydrobiol., $74: 353-370$.

Lacroix G., Lescher-Moutoué F. \& Pourriot R. 1996. - Trophic interactions, nutrient supply, and structure of freshwater pelagic food webs. In : M. Hochberg, J. Clobert \& R. Barbault (eds), As pects in the Genesis and Maintenance of Biological Diversity. Oxford University Press, Oxford : 162-179.

Langeland A. \& Reinertsen H. 1982. - Interactions between phytoplankton and zooplankton in a fertilized lake. Holarctic Ecol. $5: 253-272$.

Larsson P. 1978. - The life cycle dynamics and production of zooplankton in Ovre Heimdalsvatn. Holarctic Ecol., 1 : 162-218.

Le Cren E.D. \& Lowe-McConnell R.H. (eds) 1980. - The Functioning of Freshwater Ecosystems. IBP 22. Cambridge University Press, $588 \mathrm{p}$.

Lescher-Moutoué F. 1984. - Structure, biomasse et production des Copépodes Calanoïdes d'un écosystème lacustre peu profond (lac de Créteil, France). Acta (Ecol., CEcol. Gener., 5: 91-108.

Lescher-Moutoué F., Garnier J. \& Pourriot R. 1985. - Interactions entre les peuplements planctoniques et piscicole du lac de Créteil impact d'une reproduction exceptionnelle de Percidés. Bull. Ecol., $16: 9-17$.

Lewis W.M. Jr. 1978. - A compositional, phytogeographical and elementary structural analysis of the phytoplankton in a tropical lake: Lake Lanao, Philippines. J. Ecology, 66 : 213-226.

Likens G.E. (ed.) 1985. - An Ecosystem Approach to Aquatic Ecology. Mirror Lake and Its Environment. Springer-Verlag N.Y. : 516 p

Löffler H. (ed.) 1979. - Neusiedlersee. Limnology of a Shallow La$k e$ in Central Europe. Monographiae Biologicae 37, Dr. W. Junk bv Publishers, The Hague, 543 p.

Makarewicz J.C. \& Likens G.E. 1979. - Structure and function of the zooplankton community of Mirror Lake, New Hampshire. Ecol. Monographs : 109-127.

Mazumder A. 1994. - Phosphorus-chlorophyll relationships under contrasting zooplankton and thermal structure : predictions and patterns. Can. J. Fish. Aquat. Sci., 51 : 390-400.

Mazumder A. \& Havens K.E. 1998. - Nutrient-chlorophyll-Secchi relationships under contrasting grazer communities of temperate versus subtropical lakes. Can. J. Fish. Aquat. Sci., 55 : 1652-1662.

McCauley E., Downing J.A. \& Watson S. 1989. - Sigmoid relationships between nutrients and chlorophyll among lakes. Can. J. Fish. Aquat. Sci., 46 : 1171-1175. 
McCauley E. \& Kalff J. 1981. - Empirical relationships between phytoplankton and zooplankton biomass in lakes. Can. J. Fish. Aquat. Sci., 38 : 458-463.

McCauley E., Murdoch W.W. \& Watson S. 1988. - Simple models and variation in plankton densities among lakes. Am. Nat., 132 : 383-403.

McQueen D.J., Post J.R. \& Mills E.L. 1986. - Trophic relationships in freshwater pelagic ecosystems. Can. J. Fish. Aquat. Sci., $43: 1571-1581$

Mikulski J.ST., Adamczak B., Bittel L., Bohr R., Bronisz D., Donderski W., Gizinski A., Lucinska M., Rejewski M., Strzelczyk E., Wolnomiejski N., Zawislak W. \& Zytkowicz R. 1975. - Basic regularities of productive processes in the Ilawa lakes and in the Giplo lake from the point of vue of utility values of the water. Pol. Arch. Hydrobiol., 22 : 101-122.

Mills E.L. \& Forney J.L. 1988. - Trophic dynamics and development of freshwater pelagic food webs. In : S.R. Carpenter (ed.), Complex Interactions in Lake Communities. Springer-Verlag, New York : 11-30.

Mills E.L. \& Schiavone A. Jr. 1982. - Evaluation of fish communities through assessment of zooplankton populations and measures of lake productivity. North Amer. J. Fish. Management, 2 : 14-27.

Morgan N.C. 1980. - Secondary production. In : E.D. Le Cren \& R.H. Lowe-McConnell (eds), The Functioning of Freshwater Ecosystems. IBP $22: 247-340$.

Mori S., Saijo Y. \& Mizuno T. 1984. - Limnology of Japanese lakes and ponds. In : F.B. Taub (ed.), Lakes and Reservoirs. Ecosystems of the World, 23. Elsevier Sci. Publishers B. V : 303-329.

Neill W.E. 1988. - Complex interactions in oligotrophic lake food webs: responses to nutrient enrichment. In : S.R. Carpenter (ed.), Complex Interactions in Lake Communities. Springer-Verlag, New-York : 31-44.

Oksanen L., Fretwell S.D., Arruda J. \& Niemelä P. 1981. - Exploitation ecosystems in gradients of primary productivity. Am. Nat., $118: 240-261$.

Olrik K. 1981. - Succession of phytoplankton in response to environmental factors in Lake Arreso, North Zealand, Denmark. Schweiz. Z. Hydrol. 43 : 6-19.

Pace M.L. 1984. - Zooplankton community structure, but not biomass, influences the phosphorus-chlorophyll a relationship. Can. J. Fish. Aquat. Sci., 41 : 1089-1096.

Pace M.L. 1986. - An empirical analysis of zooplankton community size structure across lake trophic gradients. Limnol. Oceanogr., $31: 45-55$

Paloheimo J.E. \& Fulthorpe R.R. 1987. — Factors influencing plankton community structure and production in freshwater lakes. Can. J. Fish. Aquat. Sci., $44: 650-657$.

Pederson G.L., Welch E.B. \& Litt A.H. 1976. — Plankton secondary productivity and biomass: their relation to lake trophic state. Hydrobiologia, 50 : 129-144.

Perin S., Pick F.R., Lean D.R.S. \& Mazumder A. 1996. — Effects of planktivorous fish and nutrient additions on primary production of shallow versus deep (stratified) lake enclosures. Can. J. Fish. Aquat. Sci., 53 : 1125-1132.

Persson L., Andersson G., Hamrin S.F. \& Johansson L. 1988. Predator regulation and primary production along the productivity gradient of temperate lake ecosystems. In : S.R. Carpenter (ed.), Complex Interactions in Lake Communities. Springer-Verlag, New-York : 45-65.

Petersen J.E., Chen C.C. \& Kemp W.M. 1997. - Scaling aquatic primary productivity: Experiments under nutrient- and light-limited conditions. Ecology, 78 : 2326-2338.
Pinel-Alloul B., Mazumder A., Lacroix G. \& Lazzaro X. 1998. Les réseaux trophiques lacustres: structure, fonctionnement, interactions et variations spatio-temporelles. Rev. Sci. Eau, 11 : 163-197.

Power M.E. 1992. - Top-down and bottom-up forces in food webs: do plants have primacy ? Ecology, 73 : 733-746.

Prairie Y.T., Duarte C.M. \& Kalff J. 1989. - Unifying nutrientchlorophyll relationships in lakes. Can. J. Fish. Aquat. Sci., 46 : 1176-1182.

Proulx M., Pick F.R., Mazumder A., Hamilton P.B. \& Lean D.R.S. 1996. - Effects of nutrients and planktivorous fish on the phytoplankton of shallow and deep aquatic systems. Ecology, 77 : 1556-1572.

Reinertsen H. \& Langeland A. 1982. - The effect of a lake fertilization on the stability and material utilisation of a limnetic ecosystem. Holarctic Ecol., 5 : 311-324.

Rey J. \& Capblancq J. 1975. - Dynamique des populations et production du zooplancton du lac de Port-Bielh (Pyrénées Centrales). Annls Limnol., 11 : $1-45$.

Reynolds C.S., Wiseman S.W., Godfrey B.M. \& Butterwick C. 1983. - Some effects of artificial mixing on the dynamics of phytoplankton population in large limnetic enclosures. J. Plankton Res., 5 : 203-234.

Ricker W.E. 1973. - Linear regressions in fishery research. J. Fish. Res. Board Can., 30 : 409-434.

Rigler F.H. 1972. - The Char Lake projet. A study of energy flow in a high arctic lake. In: Z. Kajak \& A. Hillbricht-Ikowska (eds), Productivity Problems of Freshwaters. Warszawa-Krakow : 287-300.

Rigler F.H., McCallum M.E. \& Roff J.C. 1974. - Production of zooplankton in Char Lake. J. Fish. Res. Board Can., 31 : 637-646.

Royal Society (African Freshwater Biological Team). 1972. — Lake George, Uganda. Studies on a tropical freshwater ecosystem. In : Z. Kajak \& A. Hillbricht-Ilkowska (eds), Productivity Problems of Freshwaters. Warszawa-Krakow : 301-309.

Sarvala J. 1978. - An ecological energy budget of the Lake Päärjärvi. Lammi Notes, 1 : 12-16.

Saunders J.F. III \& Lewis W.M. Jr. 1988. - Dynamics and control mechanisms in a tropical zooplankton community (Lake Valencia, Venezuela). Ecol. Monogr., 58 : 337-353.

Scheffer M. 1998. - Ecology of Shallow Lakes. Chapman \& Hall, London, $357 \mathrm{p}$.

Schindler D.W. \& Comita G.W. 1972. - The dependence of primary production upon physical and chemical factors in a small, senescing lake, including the effects of complete winter oxygen depletion. Arch. Hydrobiol., 69 : 413-451.

Sondergaard M., Kristensen P.\& Jeppesen E. 1992. - Phosphorus release from resuspended sediment in the shallow and wind-exposed Lake Arreso, Denmark. Hydrobiologia, 228 : 91-99.

Sprules W.G. 1980. - Zoogeographic patterns in the size structure of zooplankton communities, with possible applications to lake ecosystem modeling and management. In : W.C. Kerfoot (ed.), Evolution and Ecology of Zooplankton Communities. University Press of New England, Hanover : 642-656.

Steinberg C. 1983. - Effects of artificial destratification on the phytoplankton populations in a small lake. J. Plankton Res., 5 : 855-864.

Taylor W.D. 1984.- - Phosphorus flux through epilimnetic zooplankton from Lake Ontario : relationship with body size and significance to phytoplankton. Can. J. Fish. Aquat. Sci., 41 : 1702-1712.

Tilzer M.M. 1990. - Specific properties of large lakes. In : M.M. Tilzer \& C. Serruya (eds), Ecological Structure and Function in Large Lakes. Springer-Verlag, Berlin : 39-45. 
Tilzer M.M., Gaedke U., Schweizer A., Beese B. \& Wieser T. 1991. - Interannual variability of phytoplankton productivity and related parameters in Lake Constance : no response to decreased phosphorus loading ? J. Plankton Res., 13 : 755-778.

Timms R.M. \& Moss B. 1984. - Prevention of growth of potentially dense phytoplankton populations by zooplankton grazing, in the presence of zooplanktivorous fish, in a shallow wetland ecosystem. Limnol. Oceanogr., $29: 472-486$.

Tomassone R., Lesquoy E. \& Millier C. 1983. - La Régression : Nouveaux Regards sur une Ancienne Méthode Statistique. Actualités scientifiques et agronomiques de l'INRA. Masson, Paris : $180 \mathrm{p}$.

Waters T.F. 1977. - Secondary production in inland waters. Adv. Ecol. Res., $10: 91-164$.

Watson S. \& Kalff J. 1981. - Relationships between nanoplankton and lake trophic status. Can. J. Fish. Aquat. Sci., 38 : 960-967.

Wetzel R.G. 1975. - Limnology. W. B. Saunders Company, Philadelphia : 743 p.

\section{Annex 1 : Studied lakes and literature sources.}

Annexe 1 : Liste des lacs pris en compte et références.

- Batorin, Bolshoy Kharbey, Chedenjarvi, Clear Lake, Lake n²39, Dalnee, Drivyaty, Vorderer Finstertaler See, Flosek, Karakul, Kiev Reservoir, Krasnoye, Krivoye, Krugloye, Kurakhov, Loch Leven, Mikolajskie, Myastro, Naroch, Red Lake (USSR), Rybinsk reservoir, Sniardwy, Taltowisko, Warniak, Zelenetzkoye : data in Kajak \& Hillbricht-Ilkowska 1972 and Le Cren \& Lowe-McConnel 1980.

- Baikal : Galazy 1984.

- Char : Rigler 1972, Rigler et al. 1974.

- Chester Morse : Pederson 1976.
- Constance : Geller \& Güde 1989, Tilzer et al. 1991

- Créteil : Garnier 1983, Lescher-Moutoué 1984, Lacroix 1987, unpublished data.

- Esrom : Jonasson 1984.

- Findley : Pederson et al. 1976.

- George : Royal Society, African Freshwater Biological Team 1972, Burgis 1974.

- Jyväsjärvi : Hakkari 1978.

- Kojima : Mori et al. 1984.

- Lanao : Lewis 1978.

- Langvatn : Langeland \& Reinertsen 1982, Reinertsen \& Langeland 1982.

- Mirror Lake : Likens 1985.

- Myvatn : Jonasson 1979.

- Neusiedlersee : Löffler 1979.

- Ovre Heimdalsvatn : Larsson 1978, Blakar \& Jacobsen 1979.

- Paärjärvi : Sarvala 1978.

- Paijänne : Hakkari 1978.

- Port-Bielh : Rey \& Capblancq 1975, Capblancq \& Laville 1983.

- Sammamish : Pederson et al. 1976.

- Severson : Comita 1972, Schindler \& Comita 1972.

- Snowflake : Anderson 1975.

- Tchad : Carmouze et al. 1983.

- Teardrop Pond : Anderson 1975.

- Tjeukemeer : Beattie et al. 1972, Gulati 1975.

- Tynwaldskie : Mikulski et al. 1975.

- Valencia : Saunders \& Lewis 1988.

- Vechten : Gulati 1975.

- Washington : Eggers et al. 1978.

- Wuras Dam : Grobbelaar 1985.

- Yunoko : Mori et al. 1984. 